\title{
Rapid continental spread of a salt-tolerant plant along the European road network
}

\author{
R. Fekete (1) - Gy. Haszonits • D. Schmidt $\cdot$ H. Bak $・$ O. Vincze • \\ K. Süveges $\cdot$ A. Molnár V.
}

Received: 18 September 2020/Accepted: 8 April 2021/Published online: 21 April 2021

(C) The Author(s) 2021

\begin{abstract}
The spread of alien species with the expansion of road networks and increasing traffic is a well-known phenomenon globally. Besides their corridor effects, road maintenance practices, such as the use of de-icing salts during winter facilitate the spread of halophyte (salt tolerant) species along roads. A good example is Plantago coronopus, a mainly coastal halophyte which has started spreading inland from the Atlantic and Mediterranean coastal habitats, recently reaching even Central European countries (e.g. Hungary). Here we studied the spread of this
\end{abstract}

Supplementary Information The online version contains supplementary material available at https://doi.org/10.1007/ s10530-021-02531-6.

R. Fekete $(\bowtie) \cdot$ H. Bak · K. Süveges · A. Molnár V. Department of Botany, University of Debrecen, Egyetem tér 1, Debrecen 4032, Hungary

e-mail: feketereka722@gmail.com

Gy. Haszonits · D. Schmidt

Institute of Botany and Nature Conservation, University of Sopron, Bajcsy-Zsilinszky u. 4, Sopron 9400, Hungary

O. Vincze

Department of Tisza Research, MTA Centre for

Ecological Research-DRI, Bem tér 18/C, Debrecen 4026, Hungary

O. Vincze

Evolutionary Ecology Group, Hungarian Department of Biology and Ecology, Babes-Bolyai University, Clinicilor 5-7, Cluj-Napoca 400006, Romania halophyte and tried to identify factors explaining its successful dispersion along roads, while also comparing native and non-native roadside occurrences with regard to altitude of the localities, size of roadside populations and frequency of roadside occurrences. We completed a comprehensive literature review and collected more than 200 reports of occurrence from roadsides spanning a total of 38 years. During systematic sampling the frequency of the species along roads was significantly higher in the Mediterranean (native area), than along Hungarian (non-native area) roads, however the average number of individuals at the sampling localities were very similar, and no significant difference could be detected. Using a germination experiment, we demonstrate that although the species is able to germinate even at high salt concentrations, salt is not required for germination. Indeed salt significantly decreases germination probability of the seeds. The successful spread of the species could most likely be explained by its remarkably high seed production, or some special characteristics (e.g. seed dimorphism) and its ability to adapt to a wide range of environmental conditions. Considering the recent and rapid eastward spread of $P$. coronopus, occurrences in other countries where it has not been reported yet can be predicted in coming years.

Keywords Biological invasion - Coastal species . De-icing salt $\cdot$ Halophyte $\cdot$ Roadside $\cdot$ Traffic 


\section{Introduction}

Due to globalization, road networks are growing rapidly all over the world, Europe harbours one of the longest road networks, where the length of paved roads was almost 5 million kms by the end of 2017 , out-rivaling even the United States and China (European Road Federation 2020). Roads play a prominent role in the spread of alien and invasive plant species, as road traffic and road management create favorable conditions for their dispersion (Forman and Alexander 1998; Wilcox 1989; Harrison et al. 2002; Arteaga et al. 2009; Christen and Matlack 2009; Mortensen et al. 2009; Joly et al. 2011; Rauschert et al. 2017; Skultety and Matthews 2017; Follak et al. 2018). Vehicles have a major role in the dispersal of plant propagules, by means of generating air turbulence and transporting propagule-containing soil that is attached to their tires (Ross 1986; Zwaenepoel et al. 2006; von der Lippe et al. 2013). For instance, mowing vehicles have been repeatedly shown to transport seeds along roads (Strykstra et al. 1997; Vitalos and Karrer 2009). The construction and management of roads is usually associated with several types of disturbances, such as frequent mowing, use of herbicides, trampling by humans or vehicles, introduction of a range of pollutants or propagules of alien species embedded within the modified soils used for the construction (Šerá 2008; van der Ree et al. 2015). Another management practice involves the spraying of deicing salts (most frequently $\mathrm{NaCl}$ ) during winter which has become a common practice, particularly during the last few decades (Houska 2007). De-icing salt has multifold effects on the roadside environment, causing for instance leaf damage in some evergreen tree species (Hofstra 1971), it contaminates groundwater (Amrhein et al. 1992) and soil by increasing salt content and ultimately by facilitatings the spread of halophytic plant species (Davison 1971). Halophytes are plant species, which are able to survive and reproduce in environments where salt concentrations are at least $200 \mathrm{mM} \mathrm{NaCl}$ (Flowers and Colmer 2008).

Spread of halophytes along roads is a well-known phenomenon globally (Reznicek 1980; Scott and Davison 1982; Dogan et al. 2004) and is particularly well-studied in Europe (Wróbel et al. 2006; Hohla et al. 2015; Dítě and Dítětová 2016; Kocián et al. 2016; Hanselmann 2017; Smith 2017). Several studies have shown the spread of maritime species along roads at continental parts of Europe and in the UK (Scott and Davison 1982; Scott 1985; Hohla and Melzer 2003; Hohla and Raabe 2012), but one of the most notable example among these is Plantago coronopus, which has become widespread along European roads during the last four decades (Hohla 2012; Hanselmann 2017; Ehl et al. 2019). Roadside occurrences of the species are also known from Asia (Kuwait) (Daoud 1975). It has also reached Hungary, beside other coastal species, such as Dittrichia graveolens and Cochlearia danica (Schmidt et al. 2016; Takács et al. 2016; Fekete et al. 2018). Interestingly, the native range of $P$. coronopus is largely restricted to the coastal regions of Europe, but very few studies reported its occurrence along roadsides from there (Diaz Gonzalez et al. 1988; Fraysse 1997; Trigo et al. 1999; Valladares et al. 2008; Tormo et al. 2011).

For our study, we chose four regions to survey the roadside spread of $P$. coronopus. We selected one nonnative region in our surveys, Hungary, because it represents one of the few European countries where no native (coastal) occurrences of $P$. coronopus are known. Furthermore, Hungary is also a unique country due to the large areas of natural inland alkali habitats, the Pannonian salt steppes and salt marshes where $P$. coronopus is not a native species, thus it is still not known if it is able to invade these habitats threatening natural inland alkali plant communities. We further selected two small Mediterranean islands (Cyprus and Lesbos) from the native area of the species, and to enlarge the native range in our surveys we included some parts of continental Greece, where roadside spread might start from the coasts into to the continental parts.

To advance our understanding of the status and drivers associated with the spread of Plantago coronopus along roads, we: (1) collected records of the spread of the species at roadsides from literature and reconstructed the dispersion history of the species, (2) mapped the current roadside occurrences in the native and non-native area of the species using field surveys in order to test whether the spread and population size is limited in the non-native range or these are not limited due to high similarity of roadside habitats regardless their geographic location, (3) estimated seed production as a proxy for dispersal ability and tested the effect of salt $(\mathrm{NaCl})$ on the germination of the species to see how important increased salt concentration is in roadside soils in the 
rapid spread of the species, (4) tested whether the number of other halophilic species could be related to the occurrences of $P$. coronopus, and if traffic intensity (which in other studies is a good indicator of the spread of alien plant species) affects its roadside occurrences. We further tested if there is a difference between these occurrences in the native and non-native area regarding altitude, since we assumed that due to the Mediterranean climate the species could colonize roadside habitats at higher altitudes than in Hungary. We then tested two further questions: the species is much more common along Mediterranean roads than along Hungarian roads, and the size of roadside populations is larger in the Mediterranean.

\section{Materials and methods}

\section{Literature review}

To estimate the dispersal speed and the possible routes of the colonization of European roads we searched the literature in Google Scholar using the following keywords: the name of the species 'Plantago coronopus' AND one of the following words: 'roadside', 'road','motorway', 'Auto-

bahn','Strasse','route','Strassenrand'. We checked the first 100 hits (papers) for each keyword combination, thus 700 papers altogether. After scanning these papers, the number of studies that included data on occurrences of $P$. coronopus was 47 . The following data were collected (if information was available): locality of occurrence (continent, country, settlement, exact description, geocoordinates, altitude), classification of road (road number and category), date of observation and the size of the population. When exact geocoordinates were not shown in the study we generated them based on the description of the locality, but in the case of 14 occurrences the latter was not possible. Occurrences were georeferenced using Quantum GIS 3.12.1 software.

\section{Road surveys}

We conducted road surveys in four regions within Europe, three of these were located within the native distribution range of $P$. coronopus (Greece (continental), Lesbos, Cyprus) and an additional region (Hungary), where the presence of the species was documented as an alien along roads (Table 1.). We combined data from two types of field surveys. First, a systematic search for $P$. coronopus along roads was performed. This meant, that roadside sampling points were placed at a distance of two or five kilometers apart along the surveyed road sections. In the case of motorways, we could not follow this protocol, therefore we only surveyed parking places and motorway exits where stopping with a vehicle was allowed. In every systematic sampling point we surveyed a $50 \mathrm{~m}$ road section (only right side of the road) in a lane of up to five meters, searching for $P$. coronopus. Second, a non-systematic sampling was also conducted, where we visited and surveyed sampling locations where the presence of the species was assumed based on a priori information or our knowledge on its quick spread. At both sampling location types we recorded the geocoordinates, altitude, and the number of individuals found (recorded on a $\log$ scale: 0 : no individuals; 1 : 1-9 individuals; 2: 11-99 individuals; 3: 100-999 individuals). We also recorded the presence of other halophyte plant species. Only ten species of halophytes, besides $P$. coronopus were considered in the analysis, namely species whose phenology allowed detection during the period of our field surveys. These were the following: Artemisia santonicum, Atriplex tatarica, Festuca pseudovina, Hordeum hystrix, Limonium gmelinii subsp. hungaricum, Podospermum canum, Puccinellia distans, Spergularia maritima, $S$. rubra, S. salina.

Factors affecting roadside occurrences of $P$. coronopus

We collected the traffic intensity of the year 2018 of the national roads of Hungary (Hungarian Public Road Nonprofit Pte Ltd Co. 2019) for each of the Hungarian sampling points. Traffic intensity reflects the total number of vehicles passing by a given road section in a day.

To test the effect of traffic intensity we performed two generalized linear models (GLMM), where we used presence/absence of $P$. coronopus (binomial error distribution) or the size of the populations (poisson error distribution) as dependent variables and altitude, number of other halophyte species and traffic intensity as explanatory variables. We further included the county and sampling type as random factors. To test if altitudinal variation in the frequency 
Table 1 Characteristics of the road surveys

\begin{tabular}{lclll}
\hline Region & $\begin{array}{l}\text { Number of thematic sampling } \\
\text { points }\end{array}$ & $\begin{array}{l}\text { Number of non-thematic sampling } \\
\text { points }\end{array}$ & $\begin{array}{l}\text { Year of } \\
\text { survey }\end{array}$ & $\begin{array}{l}\text { Distance between thematic } \\
\text { stops }(\mathrm{km})\end{array}$ \\
\hline Cyprus & 53 & 0 & 2020 & 5 \\
Hungary & 517 & 91 & $2013-2019$ & 5 \\
Greece & 69 & 0 & 2019 & 5 \\
Greece & 163 & 0 & 2018 & 2 \\
(Lesbos) & & & & \\
\hline
\end{tabular}

of occurrence of $P$. coronopus differs between the Mediterranean (indigenous) and Hungarian (nonindigenous) regions, we built binomial GLMMs. We used presence/absence as the dependent variable in subsequent models, with altitude, type of occurrence (indigenous or non-indigenous) and the interaction of these two as explanatory variables. Additionally, we built an LMM, where the size of population was used as the dependent variable and the type of occurrence (indigenous or non-indigenous) was included as an explanatory variable. In all three models, region (Cyprus, Hungary, Greece, Lesbos) and sampling type was used as random factor. To assess significance, we used the Satterthwaite approximation for degrees of freedom as recommended to minimize type I error (1) and implemented in the lmerTest package (2) and likelihood ratio tests for multiple-df tests (Luke 2017).

Reproductive trait measurements and germination experiments

To estimate the potential individual seed production, the number of flowering stems per individual, number of flowers per inflorescence (in 30 individuals and 30 inflorescences) and number of seeds per fruit were counted on 12 June 2020 using individuals collected from a roadside (i.e. road number 8) near Veszprém, Hungary.

In order to determine whether $P$. coronopus requires salt for germination and assess the maximum substrate $\mathrm{NaCl}$ concentration at which seeds are able to germinate, an in vitro germinability test was performed between 25 February 2019 and 10 March 2019. The seeds used for the germination test were collected on 12 August 2019 from the roadside of M7 motorway near Balatonlelle, Hungary and were stored at room temperature until the germination test started. Germination tests were performed at room temperature on a $1 \%$ agar substrate in Petri dishes with the following $14 \mathrm{NaCl}$ concentrations (mass percent):

0 (control), $0.15 \%, 0.30 \%, 0.45 \%, 0.60 \%, 0.75 \%$, $0.90 \%, 1.05 \%, 1.20 \%, 1.35 \%, 1.50 \%, 2.00 \%, 2.50 \%$, $3.00 \%$. The salt concentrations used are comparable to those in the following soil types: soils with salt content $<0.10 \%$ are not saline and these salt levels do not inhibit the growth of agricultural plants, $0.10-0.25 \%$ are slightly saline and cause a slight decrease in the growth of salt-sensitive plants, $0.25-0.50 \%$ are moderately saline and the yields of most cultivated plants decline in these soils, $0.50-1.00 \%$ are saline, in which only the growth of halophytes is unaffected, and soils with $>1.00 \%$ salt content are strongly saline, in which only a few obligate halophytes are able to persist (Stefanovits et al. 1999). 50 seeds with three replicates were germinated (in total 2100 seeds) on every concentration. During germination tests Petri dishes were placed near the window in a laboratory, under natural light conditions and germination was monitored for 14 days. To analyze germinability at various salt concentrations we used a binomial GLMM, where germination outcome (germinated/non-germinated) of seeds was used as the dependent variable and $\mathrm{NaCl}$ concentration was the sole explanatory variable, included as a second-degree orthogonal polynomial. All models included the identifier of the Petri dish as a random factor. All data analyses were carried out in the $\mathrm{R}$ statistical environment ( $\mathrm{R}$ version 3.6.3, package lme4, R Core Team 2018). 


\section{Results}

Literature review

The spread of $P$. coronopus along roads in Europe was documented between 1980 and 2019 (Table S1). Overall, the literature review revealed 203 documented occurrences of the species from 11 countries. Most of the occurrences were recorded in Germany (Fig. 1); 96 records were reported from motorways, 70 from highways and main roads and 24 from lower category roads and car parks, while in 13 reported occurrences no information was provided about the habitat. $P$. coronopus was recorded at altitudes above $1000 \mathrm{~m}$ a.s.l. on a motorway in Austria and on a main road in Germany. Between 1980 and 2000 only $15 P$. coronopus occurrences were reported from roadsides, while this number increased to 50 between 2000 and 2010, and 153 occurrences were reported between
2010 and 2018. While publication rates increased rapidly during the last four decades, which might have an influence on the latter records, the increasing speed of dispersion of $P$. coronopus is also indicated by documented spread of the species by several earlier works as well as floristic records in multiple regions. 82 documented occurrences also reported information about the size of the population. In 22 studies only a few (1-10) individuals were recorded, 39 studies mention 10-100 individuals, in 13 studies the number of individuals varied between 100 and 1000, while 65 studies reported the presence of more than 1000 individuals. Our literature review further revealed the roadside occurrence of $P$. coronopus in Kuwait (Asia) (Daoud 1975) and in Tasmania (Australia) (Baker 2005).

From Hungary 77 occurrences of $P$. coronopus were reported in the surveyed literature. The first occurrence was reported from 2013 and additional

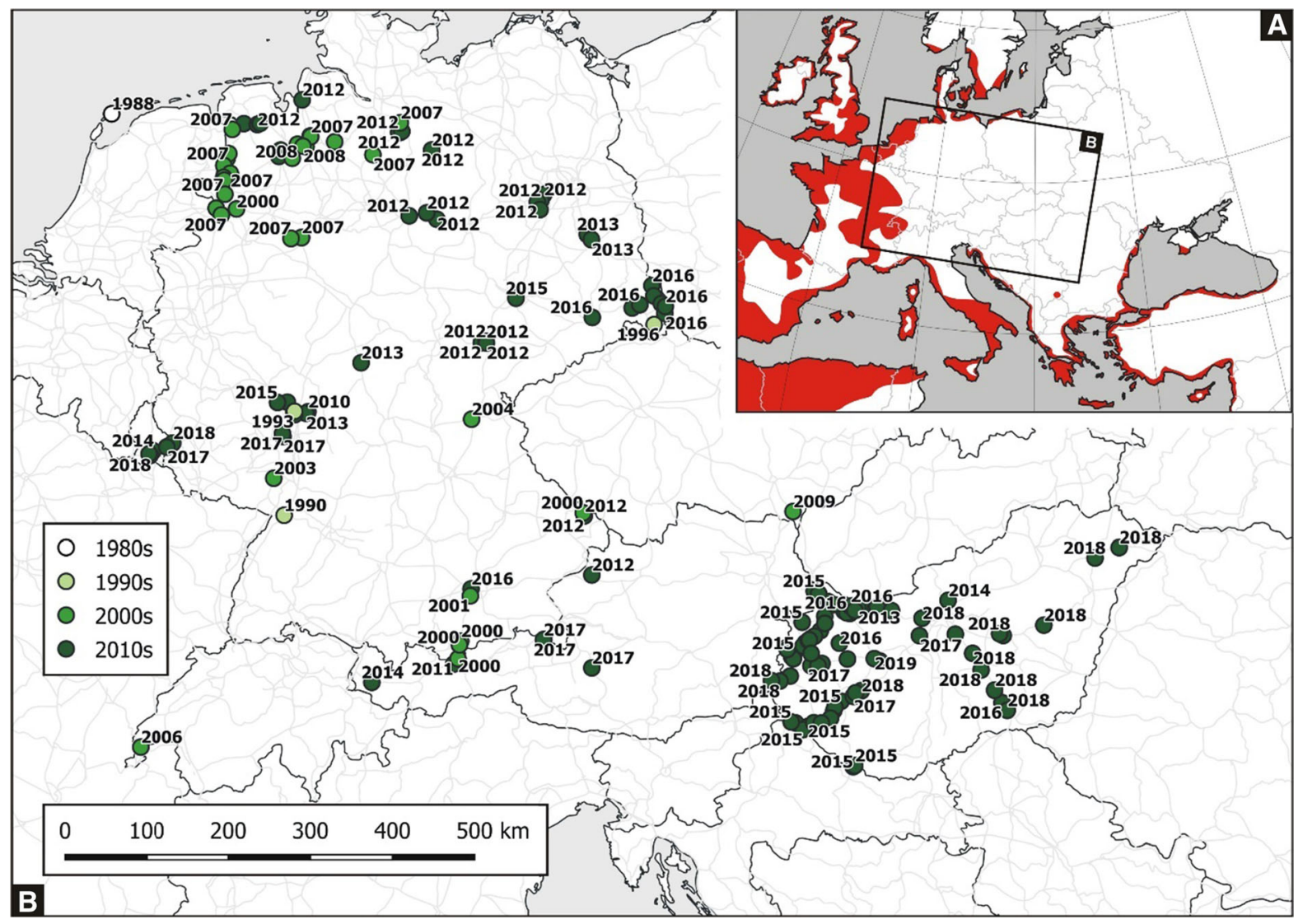

Fig. 1 A Native distribution range of $P$. coronopus (Haeupler and Schönfelder 1989, Villellas et al. 2013, Zając and Zając 2001, CABI 2021, Nikolić 2021). B European roadside occurrences found in the literature (occurrences from Spain, Turkey and the UK are not shown in the map) 
records are available from the past six years. The location of the first reported occurrence of the species in 2013 and the population located the farthest from this within Hungary in 2018 are $390 \mathrm{kms}$ apart, a distance covered by the species within five years. The first roadside occurrences of the species close to the original coastal habitats derives from the Netherlands, thus if we hypothesize, that the species started its continental spread there, it traveled $1383 \mathrm{~km}$ from the Netherlands to reach Hungary within 25 years. Although, somewhat speculative, if the occurrence data are reliable, we estimate that the average dispersal speed of $P$. coronopus along European roads to be $67 \mathrm{~km} /$ year.

Road surveys

During the non-systematic sampling process from the 91 sampling points within Hungary we found $P$. coronopus at 56 localities. A further 17 occurrences were found along Hungarian roads during systematic sampling and four occurrences were found opportunistically in 2020 (Biharkeresztes, Jánosháza, Örkény, Székesfehérvár). Systematic sampling indicated that the species is most frequently encountered on Cyprus and least frequently in Hungary among the surveyed countries (Fig. 2.). Within the Mediterranean region, such as in Greece and Lesbos, $P$. coronopus was also more frequently encountered at roadside verges than in Hungary (Table 2.).

Factors affecting roadside occurrence of $P$. coronopus

Within Hungary, we found that the presence of $P$. coronopus was not affected by altitude, while the probability of occurrence was significantly higher in sampling locations with higher numbers of co-occurring halophyte species. Additionally, increasing traffic intensity was associated with higher probability of $P$. coronopus presence. In the case of population sizes the same patterns were found, larger populations being associated with higher number of co-occurring halophytes and more intensive traffic, but altitude also had a significant effect, with low altitude populations being larger (Table 3.).

We found that $P$. coronopus is significantly more frequent along roads in the surveyed Mediterranean islands, than in Hungary. P. coronopus occurred at similar altitudes in Hungary and within its native range where we conducted surveys. Population size at the sampling localities did not differ significantly between the Mediterranean and Hungarian regions (Table 4.).

Reproductive trait measurements and germination experiments

According to the reproductive trait measurements, the average number of flowering stems of a $P$. coronopus individual is nine and the average number of flowers per inflorescence is 32 . The average number of seeds per one capsule is 4.33 , thus the estimated seed production is 1247 seed per individual plant.

From the 2100 seeds tested, 721 germinated. Germination rate was the highest in the control Petri dishes $(93 \%)$, but was also high at $0.15 \%$ (82\%), $0.3 \%(89 \%)$ and $0.45(82 \%) \% \mathrm{NaCl}$ concentration. A moderate decrease in germination was observed at $0.6 \% \mathrm{NaCl}$ concentration, where only $66 \%$ of the tested seeds germinated. The highest $\mathrm{NaCl}$ concentration where seed germinated was $0.9 \%$. From 1.05 to $3 \%$ salt concentration no seed germinated. GLMM showed a significant negative quadratic effect $(p<0.001)$ of $\mathrm{NaCl}$ concentration on germination (Table 5, Fig. 3.).

\section{Discussion}

As a response to climate change many species are faced with a shift in their geographic distribution or even an expansion of their range from warm climate regions into previously colder regions (Walther et al. 2002) resulting in the spread of exotic species and severe biodiversity loss at newly colonised sites (Van der Putten et al. 2010). The spread of exotic species is also enhanced globally by growing road networks and traffic, facilitating the role of roadside as ecological corridor for alien species (Hodkinson and Thompson 1997, Medvecká 2018).

According to our study, Plantago coronopus is spreading rapidly along European roads, and roadsides seem to act as an effective ecological corridor for the species, since we found, that growing traffic intensity enhances its roadside occurrences. We have found, that some special reproductive characteristics, like high seed production or seed dimorphism might play a key role in the spread of alien species, furthermore the 

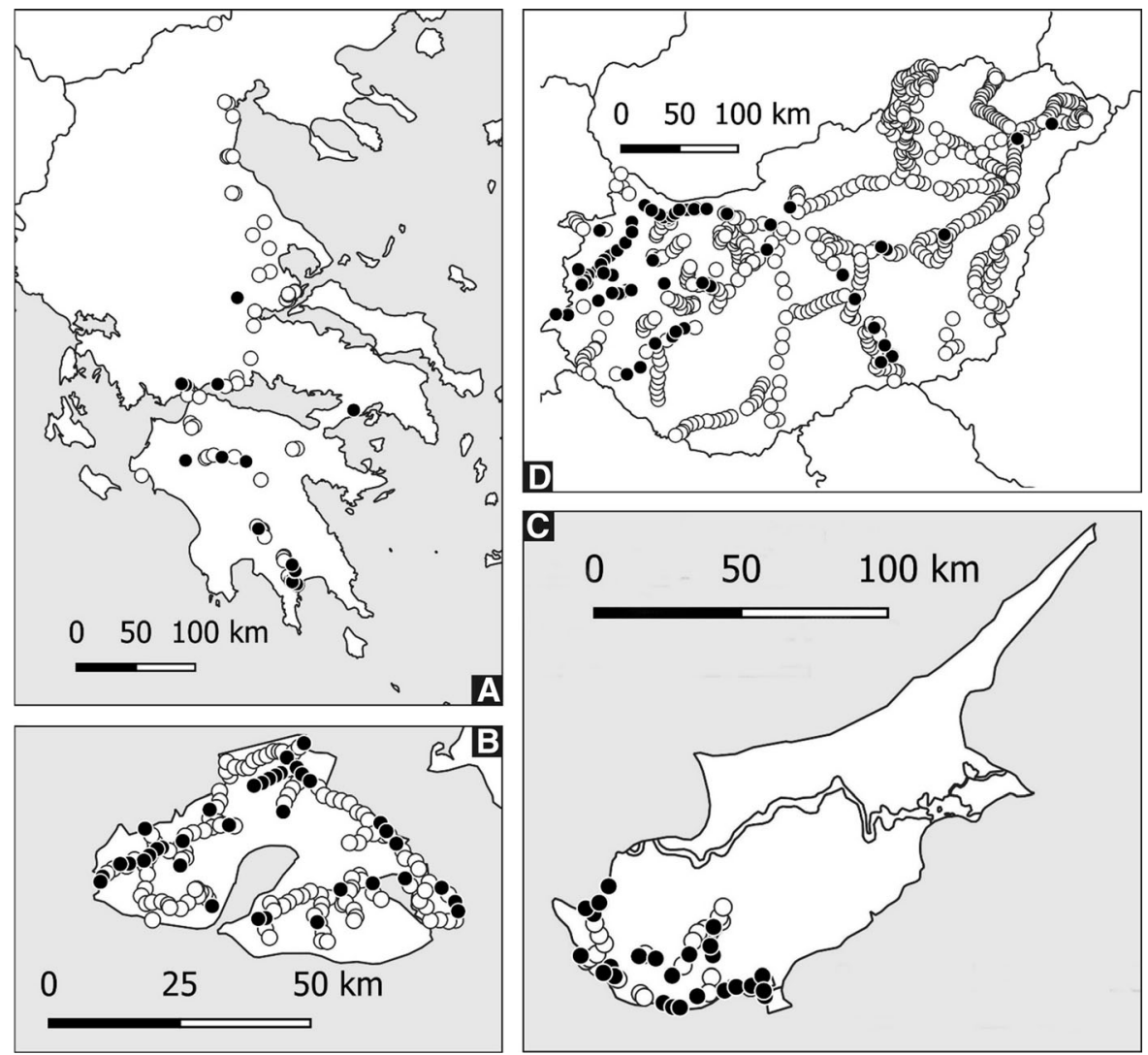

Fig. 2 Distribution of the sampling points in the Mediterranean region and Hungary. Filled dots indicate sampling points with the presence of $P$. coronopus and open dots indicate the absence

of the species. A Continental region of Greece. B Lesbos. C Cyprus. D Hungary

Table 2 Characteristics of the thematic sampling points in the surveyed countries

\begin{tabular}{lll}
\hline Region & $\begin{array}{l}\text { Ratio of sampling points with the presence of P. coronopus } \\
(\%)\end{array}$ & $\begin{array}{l}\text { Average }( \pm \text { SD) population size at the sampling } \\
\text { points }\end{array}$ \\
\hline Cyprus & 49.1 & $15 \pm 34$ \\
Hungary & 3.5 & $8 \pm 27$ \\
Greece & 23.2 & $4 \pm 17$ \\
Greece & 22.7 & $6 \pm 20$ \\
$\quad$ Lesbos) & & \\
\hline
\end{tabular}

use of roadsides as corridors is also facilitated by the salt tolerance of plants.

Literature review and road surveys

Recordings of the spread of $P$. coronopus along roads dates back to nearly 40 years, and the number of articles documenting this phenomenon has increased rapidly. This fast range expansion might be explained by the expansion of the road network and intensifying traffic in the surveyed region. A recent study demonstrated that high road density is a key factor that explains high non-native functional diversity (Zeeman et al. 2018). P. coronopus has also been documented 
Table 3 Minimal models explaining variation in the presence and the population size of $P$. coronopus along Hungarian roads

Table 4 Models showing the differences between the Mediterranean (indigenous) and Hungarian (nonindigenous) occurrences

\begin{tabular}{|c|c|c|c|c|}
\hline & Estimate & SE & $t$ value & $p$ value \\
\hline \multicolumn{5}{|l|}{ Presence/absence (GLMM) } \\
\hline Intercept & -3.38 & 0.73 & -4.62 & $p<0.001$ \\
\hline Number of halophyte species & 0.91 & 0.22 & 4.06 & $p<0.001$ \\
\hline Traffic intensity & 0.58 & 0.21 & 2.83 & 0.0047 \\
\hline \multicolumn{5}{|l|}{ Size of population (LMM) } \\
\hline Intercept & 0.65 & 0.28 & 2.29 & 0.365 \\
\hline Number of halophyte species & 0.15 & 0.04 & 3.72 & $p<0.001$ \\
\hline \multirow[t]{2}{*}{ Traffic intensity } & 0.13 & 0.05 & 2.98 & 0.003 \\
\hline & Estimate & SE & $t$ value & $p$ value \\
\hline \multicolumn{5}{|l|}{ Presence/Absence (GLMM) } \\
\hline Intercept & 1.04 & 1.40 & 0.74 & 0.46 \\
\hline Non-indigenous occurrences & -2.47 & 0.62 & -3.98 & $p<0.001$ \\
\hline \multicolumn{5}{|l|}{ Presence/Absence (GLMM) } \\
\hline Intercept & 1.15 & 1.41 & 0.81 & 0.417 \\
\hline Altitude & -0.21 & 0.10 & -2.19 & 0.028 \\
\hline Non-indigenous occurrences & -2.62 & 0.70 & -3.75 & $p<0.001$ \\
\hline Interaction & -0.00 & 0.45 & -0.01 & 0.993 \\
\hline \multicolumn{5}{|l|}{ Population size (LMM) } \\
\hline Intercept & 1.99 & 1.28 & 1.57 & 0.351 \\
\hline Non-indigenous occurrences & -0.67 & 0.44 & -1.55 & 0.283 \\
\hline
\end{tabular}

Table 5 GLMM showing the quadratic effect of $\mathrm{NaCl}$ on seed germination

\begin{tabular}{lrrrr}
\hline & Estimate & SE & t value & $p$ value \\
\hline Intercept & -2.09 & 0.30 & -7.05 & $p<0.001$ \\
Poly $(\mathrm{NaCl}$ concentration)1 & -173.62 & 14.61 & -11.89 & $p<0.001$ \\
Poly $(\mathrm{NaCl}$ concentration)2 & -61.89 & 10.51 & -5.89 & $p<0.001$ \\
\hline
\end{tabular}

from motorways, where its presence is most likely explained by the very intensive traffic typical to highways (Hungarian Public Road Nonprofit Pte Ltd Co. 2019), and where seed dispersal might be accelerated by the large number of commuting vehicles. The species probably started its southeastward spread toward the middle of the continent from its native habitats situated at the northwestern coasts of Europe. Thus, it is very likely that the species arrived to Hungary through Austria (Schmidt et al. 2016). This is also supported by the observation that in the year when the first occurrence of the species in Hungary was recorded (2013) six occurrences were found along roads in the Western parts of the country, within $50 \mathrm{~km}$ to the Austrian border. As of today, the number of registered locations with $P$. coronopus has increased to 73 along Hungarian roads. Based on the data gathered during the literature review, we estimate the dispersal speed of $P$. coronopus along European roads to be around $64 \mathrm{~km} / \mathrm{year}$, a highly comparable dispersal speed to another coastal halophyte, Cochlearia danica, which also spreads rapidly (62-65 km/year) using the European road network (Fekete et al. 2018). 


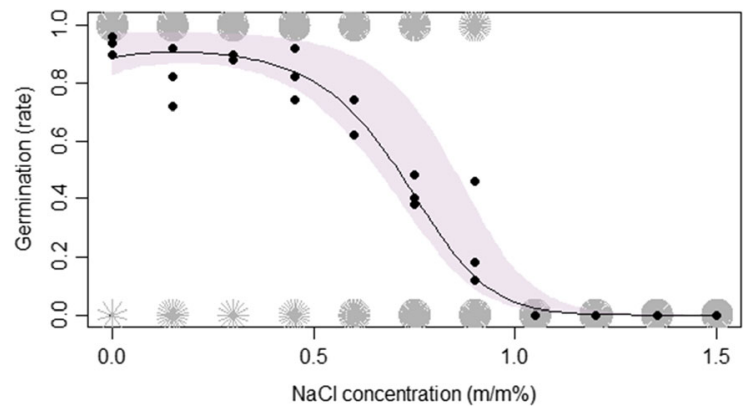

Fig. 3 Sunflower plot showing the relationship between germination and substrate $\mathrm{NaCl}$ concentration. Each petal of the sunflowers represents a single seed (germinated vs. not). Black dots show the proportion of seeds that germinated in each petri dish (three repeats with 50 seeds in each treatment)

Factors affecting the roadside occurrences

We found that the Hungarian occurrences of $P$. coronopus were positively associated with the occurrence of other halophytes, indicating that halophyte plant species have similar habitat preferences along roads. Nonetheless, sometimes different salt-tolerant species colonize different microhabitats, situated at various distances from the road edge and are therefore not only colonizing the close vicinity of roads. $P$. coronopus was often found to form large monodominant patches where no other or only a few halophytes grew in the immediate vicinity of these. According to our prediction, traffic intensity had a significant positive effect on the probability of presence of the species and also on its population size.

$P$. coronopus was shown to be more frequent along roads within its native distribution range in the Mediterranean, than along Hungarian roads, but the average number of individuals were similar in the two regions. Newly occupied habitats probably provide favorable environmental conditions for the species, such as free soil surfaces, low competition and high dispersal potential due to traffic. We initially assumed that $P$. coronopus reaches higher altitudes in the Mediterranean region than in Hungary, but no significant difference in altitude was detected between the documented Hungarian and Mediterranean occurrences. Thus, it appears that high altitude alone is not a limiting factor to the spread of $P$. coronopus, given that suitable open microhabitats are available at the roadsides.
Reproductive traits and germination

We found a remarkably high seed production potential in $P$. coronopus, with a particular individual observed to have produced more than 1200 seeds. This seed number is three times higher than the seed production of $C$. danica, however salt tolerance was also remarkably lower in case of $P$. coronopus (Fekete et al. 2018). According to LEDA database seed number per individual can be up to 2392 in case of P. coronopus (Kleyer et al. 2008). We found that the highest substrate salt concentration where seed were able to germinate was $0.9 \% \mathrm{NaCl}$. Under natural circumstances this corresponds to saline soil, where only the growth of halophytes is uninterrupted (Stefanovits et al. 1999). Another study documented that the species germinates even at $2 \%$ substrate salt content, emphasizing that seeds of $P$. coronopus are highly resistant to salt, seeds not being injured by high salt content and once salinity decreases, the seeds are able to germinate (Dowling 1933). In the case of another halophyte (Arthrocnemum indicum) characterized by dimorphic seeds, no significant difference in salt tolerance could be detected between the two types of seeds (Khan and Gul 1998). Surveys in connection with $C$. danica showed that soil salt concentration at roadside soils is much lower than the salt tolerance of this species (Fekete et al. 2018) and according to our present findings is lower than the salt tolerance of $P$. coronopus as well. Thus, theoretically the roadside salt concentration itself does not limit the spread of these halophytes. These findings suggest, that the success of these species is not solely explained by their high salt tolerance, but also by their high seed production, and also by some of their special reproductive characteristics. For instance, $P$. coronopus reproduces both by vegetative and generative means, but the latter only occurs under very specific circumstances. Moreover, a single seed capsule of $P$. coronopus contains two kinds of seeds, usually a total of five; four larger in the bottom of the capsule and one smaller seed in the upper part of the capsule. Both of these seed forms can successfully produce a new plant (Dowling 1933), but according to a former study, large seeds produce larger reproductive biomass than small seeds (Koelewijn 2004). Seed dimorphism could play an important role in dispersal, and could be an evolutionary stable strategy in heterogenous habitats (Dowling 1933; Geritz 1995). P. coronopus naturally 
occurs in a wide variety of habitats (natural marshlands, dry sand dunes, moist mountain and coastal meadows) (Imbert 2002), while during its spread along roads the species has been documented to occur under several different environmental and climatic conditions. Seed dimorphism is considered as a bethedging strategy, reducing the risk of parental investment and maximizing fitness potential under various environmental scenarios using seeds that differ markedly (Imbert 2002). The two seed types of $P$. coronopus behave differently when floating in water, while the large seeds sink within half an hour, the small seeds are able to float for over $48 \mathrm{~h}$ and then are capable of germination in water. Furthermore, small seeds exhibit a delay in their germination time compared to large seeds, resulting in populations in which flowering individuals are found at almost any time of the vegetative period (Dowling 1933). The success of the species could be further enhanced by its growth characteristics, that rank $P$. coronopus among 'fast growing' species (Grime and Hunt 1975; Lambers et al. 1989). According to Koelewijn (2004), P. coronopus could be classified as an R-type species, characterized by considerable tolerance for high levels of disturbance and by an ability to rapidly adjust its relative growth rate according to nutrient availability.

Future spread and its consequences

Based on the recent eastward spread of $P$. coronopus, we predict further occurrences to be detected in the near future in areas of Eastern Europe where the presence of the species has not been confirmed yet. Botanical surveys of roadsides habitats will be important to follow the spread of alien species, while regular monitoring of natural inland alkali habitats in proximity to known roadside occurrences of $P$. coronopus is also recommended in order to document its spread and naturalization away from roads. For further researches, it will be important to include bare ground as a predictor, since it might have a key role in the rapid spread of halophytes along roads, when salt tolerance is only a supporting factor for these species having a competitional advantage over other roadside weeds without salt tolerance. Examination of reproductive traits and growth characteristics of potential invasive species would be also important to be aware of potential threats to natural communities. It is yet unknown whether $P$. coronopus behaves as an alien under natural inland alkali habitats, and if it is able to become an invasive species threatening these native plant communities at such sites. Spread of non-native species into natural habitats is a well-known phenomenon (Barbosa et al. 2010; Pollnac et al. 2012; McDougall et al. 2018). Furthermore P. coronopus have already become an invasive alien species in the USA, where it threatens endangered plant species (US Fish and Wildlife Service 2008a, b) growing in coastal habitats. Thus, it seems that in countries where there are suitable coastal habitats, similar to the ones in the native range of $P$. coronopus, it invades these instead of roadside habitats. Besides ecological risks, the allergic ability of Plantago pollen could contribute to human health problems (Iglesias-Otero et al. 2015) and as a weed in crop fields it can further cause problems in food production (Cirujeda et al 2011). It seems that in case of $P$. coronopus not the high salt tolerance, but rather its peculiar reproductive and growth characteristics explain its successful invasion along roads across Europe.

Our results indicate that growing traffic intensity increases the dispersal potential of alien species along roads, and as demonstrated by $P$. coronopus high reproductive output and seed dimorphism might aid the establishment of large populations away from its native distribution range.

Acknowledgements The authors are thankful to Renáta Urgyán and Viktor Löki for their assistance during fieldwork, and Tünde Abonyi for her help in the germination experiments. We would like to express our thanks to the editor and to the anonymous reviewer for their valuable comments and useful suggestions.

Author's contribution AMV and DS contributed to the study conception and design. AMV, DS, GYH, KS and RF contributed to field surveys. GYH collected the data for the literature review. $\mathrm{HB}$ and RF carried out the reproductive trait summaries and germination experiments. $\mathrm{OV}$ and $\mathrm{RF}$ were responsible for statistical analyses and RF wrote the first draft of the manuscript.

Funding Open access funding provided by University of Debrecen. This research was supported by NKFI-OTKA K132573 project. RF was funded by the New National Excellence Programme of the Hungarian Ministry for Innovation and Technology (ÚNKP-20-3-II-DE-17). OV was supported by the Janos Bolyai Research Scholarship of the Hungarian Academy of Sciences and by the New National Excellence Programme of the Hungarian Ministry of Innovation and Technology. 
Data availability All sample data used in the analyses will be available from Dryad.

\section{Declarations}

Conflict of interest The authors have no conflicts of interest or competing interest.

Open Access This article is licensed under a Creative Commons Attribution 4.0 International License, which permits use, sharing, adaptation, distribution and reproduction in any medium or format, as long as you give appropriate credit to the original author(s) and the source, provide a link to the Creative Commons licence, and indicate if changes were made. The images or other third party material in this article are included in the article's Creative Commons licence, unless indicated otherwise in a credit line to the material. If material is not included in the article's Creative Commons licence and your intended use is not permitted by statutory regulation or exceeds the permitted use, you will need to obtain permission directly from the copyright holder. To view a copy of this licence, visit http://creativecommons.org/licenses/by/4.0/.

\section{References}

Amrhein C, Strong JE, Mosher PA (1992) Effect of deicing salts on metal and organic matter mobilization in roadside soils. Environ Sci Technol 26:703-709. https://doi.org/10.1021/ es00028a006

Arteaga MA, Delgado JD, Otto R, Fernández-Palacios JM, Arévalo JR (2009) How do alien plants distribute along roads on oceanic islands? A case study in Tenerife. Canary Islands Biol Invasions 11(4):1071-1086. https://doi.org/ 10.1007/s10530-008-9329-8

Barbosa NP, Fernandes GW, Carneiro MA, Júnior LA (2010) Distribution of non-native invasive species and soil properties in proximity to paved roads and unpaved roads in a quartzitic mountainous grassland of southeastern Brazil (rupestrian fields). Biol Invasions 12(11):3745-3755. https://doi.org/10.1007/s10530-010-9767-y

CABI, 2021. Plantago coronopus. In: Invasive Species Compendium. Wallingford, UK: CAB International. www.cabi. org/isc. Accessed 15 Jan 2021

Christen DC, Matlack GR (2009) The habitat and conduit functions of roads in the spread of three invasive plant species. Biol Invasions 11(2):453-465. https://doi.org/10. 1007/s10530-008-9262-x

Cirujeda A, Aibar J, Zaragoza C (2011) Remarkable changes of weed species in Spanish cereal fields from 1976 to 2007. Agron Sustain Dev 31(4):675-688

Daoud HS (1975) The genus plantago in Kuwait. J Univ Kuwait (Sci) 2:35-57

Davison AW (1971) The effects of de-icing salt on roadside verges: I-Soil and plant analysis. J Appl Ecol 8:555-561. https://doi.org/10.2307/2402891

Dítě D, Dítětová Z (2016) Halophytes spreading along roadsides of northern Slovakia. Thaiszia J Bot 26(2):165-172
Dogan Y, Baslar S, Celik A, Mert HH, Ozturk M (2004) A study of the roadside plants of west Anatolia. Turkey Nat Croat 13(1):63-80

Dowling RE (1933) The reproduction of Plantago coronopus: an example of morphological and biological seed dimorphism. Ann Bot 47(188):861-872. https://doi.org/10.1093/ oxfordjournals.aob.a090422

Ehl S, Mildenberger K, Frankenberg T, Ries C (2019) Halophytes in roadside habitats: a survey of salt-tolerant vascular plant species along roads in Luxembourg. Bull Soc Nat Luxemb 121:37-51

European Road Federation (2020) European road statistics: Yearbook 2020. URL: https://erf.be/statistics/roadnetwork-2020/. Accessed 14 Jan 20201

Fekete R, Mesterhazy A, Valkó O, Molnár VA (2018) A hitchhiker from the beach: the spread of the maritime halophyte Cochlearia danica along salted continental roads. Preslia 90:23-37. https://doi.org/10.23855/preslia. 2018.023

Flowers TJ, Colmer TD (2008) Salinity tolerance in halophytes*. New Phytol 179(4):945-963

Follak S, Schleicher C, Schwarz M (2018) Roads support the spread of invasive Asclepias syriaca in Austria. Die Bodenkultur J Land Manag Food Environ 69(4):257-265. https://doi.org/10.2478/boku-2018-0022

Forman RT, Alexander LE (1998) Roads and their major ecological effects. Ann Rev Ecol Syst 29:207-231. https://doi. org/10.1046/j.1466-822x.1998.00308.x

Fraysse JP (1997) Compte rendu de la Session de botanique méditerranéenne en Andalousie, région de Ronda, du 22 au 26 avril 1996. Bull Mens Soc Linn Lyon 66(6):157-161

Geritz SA (1995) Evolutionarily stable seed polymorphism and small-scale spatial variation in seedling density. Am Nat 146(5):685-707. https://doi.org/10.1086/285820

Grime JP, Hunt R (1975) Relative growth-rate: its range and adaptive significance in a local flora. J Ecol. https://doi.org/ $10.2307 / 2258728$

Hanselmann D (2017) Neue Zierde für den Straßensaum-Erstnachweis von Limonium gmelini (Willd.) Kuntze in Deutschland (und weitere Anmerkungen zu aktuellen Entwicklungen der Straßenbegleitflora in RheinlandPfalz). Archiv 54:155-167

Harrison S, Hohn C, Ratay S (2002) Distribution of exotic plants along roads in a peninsular nature reserve. Biol Invasions 4(4):425-430

Haeupler H, Schönfelder P (eds) (1989) Atlas der Farn- und Blütenpflanzen der Bundesrepublik Deutschland, 2nd edn. Verlag Eugen Ulmer, Stuttgart

Hodkinson DJ, Thompson K (1997) Plant dispersal: the role of man. J Appl Ecol 34(6):1484-1496

Hofstra G, Hall R (1971) Injury on road-side trees: leaf injury on pine and white cedar in relation to foliar levels of sodium chloride. Can J Bot 49:613-622. https://doi.org/10.1139/ b71-097

Hohla M, Melzer H (2003) Floristisches von den Autobahnen der Bundesländer Salzburg, Oberösterreich. Niederösterreich und Burgenland Linzer biol Beiträge 25(2):1307-1326

Hohla M, Raabe U (2012) Cochlearia danica-das Dänische Löffelkraut-kein überraschender Neuzugang der Flora von Oberösterreich. Stapfia 97:206-209 
Hohla M, Diewald W (2015) Király BG (2015) Limonium gmelini-eine Steppenpflanze an österreichischen Autobahnen sowie weitere Neuigkeiten zur Flora Österreichs. Stapfia 103:127-150

Houska C (2007) Deicing salt-recognizing the corrosion threat. International Molybdenum Association, Pittsburgh, pp $1-10$

Hungarian public road nonprofit Pte Ltd Co. (2019) URL: https://internet.kozut.hu/. Accessed 25, June 2020

Iglesias-Otero MA, Fernández-González M, Rodríguez-Caride D, Astray G, Mejuto JC, Rodríguez-Rajo FJ (2015) A model to forecast the risk periods of Plantago pollen allergy by using the ANN methodology. Aerobiologia 31(2):201-211

Imbert E (2002) Ecological consequences and ontogeny of seed heteromorphism. Persp Plant Ecol 5(1):13-36. https://doi. org/10.1078/1433-8319-00021

Joly M, Bertrand P, Gbangou RY, White MC, Dubé J, Lavoie C (2011) Paving the way for invasive species: road type and the spread of common ragweed (Ambrosia artemisiifolia). Environ Manag 48(3):514-522. https://doi.org/10.1007/ s00267-011-9711-7

KhanGul MAB (1998) High salt tolerance in germinating dimorphic seeds of Arthrocnemum indicum. Int J Plant Sci 159(5):826-832. https://doi.org/10.1086/297603

Kleyer M, Bekker RM, Knevel IC, Bakker JP, Thompson K, Sonnenschein M, Poschlod P, Van Groenendael JM, Klimes L, Klimesová J, Klotz S, Rusch GM, Hermy M, Adriaens D, Boedeltje G, Bossuyt B, Dannemann A, Endels P, Götzenberger L, Hodgson JG, Jackel A-K, Kühn I, Kunzmann D, Ozinga WA, Römermann C, Stadler M, Schlegelmilch J, Steendam HJ, Tackenberg O, Wilmann B, Cornelissen JHC, Eriksson O, Garnier E, Peco B (2008) The LEDA Traitbase: a database of life-history traits of Northwest European flora. J Ecol 96:1266-1274

Kocián P, Danihelka J, Lengyel A, Jun JC, Duchacek M, Kúr P (2016) Limonka Gmelinova (Limonium gmelinii) na dálnicích České republiky. Acta Rer Nat 19:1-6

Koelewijn HP (2004) Rapid change in relative growth rate between the vegetative and reproductive stage of the life cycle in Plantago coronopus. New Phytol 163(1):67-76. https://doi.org/10.1111/j.1469-8137.2004.01078.x

Lambers H, Cambridge ML, Konings H, Pons TL (1989) Causes and consequences of variation in growth rate and productivity of higher plants. SPB Academic Publishing, The Hague. https://doi.org/10.1016/0031-9422(91)84164-n

Luke SG (2017) Evaluating significance in linear mixed-effects models in R. Behav Res Methods 49(4):1494-1502

McDougall KL, Lembrechts J, Rew LJ, Haider S, Cavieres LA, Kueffer C, Milbau A, Naylor BJ, Nuñez MA, Pauchard A, Seipel T, Speziale KL, Wright GT, Alexander JM (2018) Running off the road: roadside non-native plants invading mountain vegetation. Biol Invasions 20(12):3461-3473. https://doi.org/10.1007/s10530-018-1787-z

Medvecká J, Zaliberová M, Májeková J, Senko D, Jarolímek I (2018) Role of infrastructure and other environmental factors affecting the distribution of alien plants in the Tatra Mts. Folia Geobot 53(3):349-364

Mortensen DA, Rauschert ES, Nord AN, Jones BP (2009) Forest roads facilitate the spread of invasive plants. Invas Plant
Sci Mana 2(3):191-199. https://doi.org/10.1614/ipsm-08125.1

Nikolić T ed. (2021) Flora Croatica Database (URL http://hirc. botanic.hr/fcd). Faculty of Science, University of Zagreb. Accessed 15, Jan 2021

Pollnac F, Seipel T, Repath C, Re LJ (2012) Plant invasion at landscape and local scales along roadways in the mountainous region of the Greater Yellowstone Ecosystem. Biol Invasions 14(8):1753-1763. https://doi.org/10.1007/ s10530-012-0188-y

R Core Team (2016): A language and environment for statistical computing. R Foundation for Statistical Computing, Vienna, Austria. https://www.R-project.org/

Rauschert ES, Mortensen DA, Bloser SM (2017) Human-mediated dispersal via rural road maintenance can move invasive propagules. Biol Invasions 19(7):2047-2058. https://doi.org/10.1007/s10530-017-1416-2

Reznicek AA (1980) Halophytes along a Michigan Roadside with comments on the occurrence of halophytes in Michigan. Michigan Botanist (USA).

Ross SM (1986) Vegetation change on highway verges in southeast Scotland. J Biogeogr 13:109-117. https://doi.org/10. 2307/2844986

Schmidt D, Király G, Horváth A, Szücs P (2014) Autópályán érkező tengerparti jövevény: A Plantago coronopus L. Magyarországon [Plantago coronopus L. in Hungary: a new adventive species coming from the European seashore]. - X. 'Aktuális Flóra- és Vegetációkutatás a Kárpátmedencében' Konferencia absztraktkötete, pp. 203-204

Scott NE (1985) Road de-icing salt and the invasion of verges by halophytes. Doctoral dissertation, Newcastle University

Scott NE, Davison AW (1982) De-icing salt and the invasion of road verges by maritime plants. Watsonia 14:41-52

Šerá B (2008) Road vegetation in Central Europe: an example from the Czech Republic. Biologia 63(6):1085-1088. https://doi.org/10.2478/s11756-008-0152-6

Skultety D, Matthews JW (2017) Urbanization and roads drive non-native plant invasion in the Chicago Metropolitan region. Biol Invasions 19(9):2553-2566. https://doi.org/ 10.1007/s10530-017-1464-7

Smith P (2017) Some interesting salt-tolerant plants of roadsides in the Outer Hebrides. Hebridean Nat 16:15-23

Stefanovits P, Filep Gy, Füleky Gy (1999) Talajtan [Pedology]: Mezőgazda Kiadó, Budapest. 422 pp

Strykstra RJ, Verweij GL, Bakker JP (1997) Seed dispersal by mowing machinery in a Dutch brook valley system. Acta Bot Neerl 46:387-401. https://doi.org/10.1111/plb.1997. 46.4.387

Takács A, Baráth K, Csiky J, Csikyné RÉ, Király G (2016) Taxonomical and chorological notes 3 (28-37). Studia Bot Hung 47(2):345-357

Tormo R, Silva I, Gonzalo Á, Moreno A, Pérez R, Fernández S (2011) Phenological records as a complement to aerobiological data. Int J Biomet 55:51-65. https://doi.org/10. 1007/s00484-010-0308-2

Trigo MM, Fernandez Ruiz MC, Salvo AE (1990) Sobre la palinología de las especies anemófilas más frecuentes en bordes de caminos de la ciudad de Málaga. In: FernándezFernández MC, Garrido MR, Rodríguez-García IM, Romero-García AT (eds) Blanca-López G, Díaz de la 
Guardia C. Polen Esporas y sus aplicaciones. Universidad de Granada, pp 355-362

US Fish and wildlife service (2008a) Jesup's milk-vetch (Astragalus robbinsii var. jesupii) 5-Year Review: Summary and Evaluation., USA: US Fish and Wildlife Service, 14 pp

US Fish and Wildlife Service (2008b) Showy Indian Clover (Trifolium amoenum) 5-Year review: summary and evaluation., USA: US Fish and Wildlife Service, $12 \mathrm{pp}$

Valladares F, Tena D, Matesanz S, Bochet E, Balaguer L, CostaTenorio M, Tormo J, García-Fayos P (2008) Functional traits and phylogeny: what is the main ecological process determining species assemblage in roadside plant communities? J Veg Sci 19:381-392. https://doi.org/10.3170/ 2008-8-18378

Van der Putten WH, Macel M, Visser ME (2010) Predicting species distribution and abundance responses to climate change: why it is essential to include biotic interactions across trophic levels. Philos Trans R Soc Lond B Biol Sci 365(1549):2025-2034

van der Ree R, Smith DJ, Grilo C (2015) Handbook of Road Ecology. Wiley-Blackwell, Oxford

Villellas J, Ehrlén J, Olesen JM, Braza R, García MB (2013) Plant performance in central and northern peripheral populations of the widespread Plantago coronopus. Ecography 36(2):136-145

Vitalos M, Karrer G (2009) Dispersal of Ambrosia artemisiifolia seeds along roads: the contribution of traffic and mowing machines. Neobiota 8:53-60

von der Lippe M, Bullock JM, Kowarik I, Knopp T, Wichmann M (2013) Human-mediated dispersal of seeds by the airflow of vehicles. PLoS ONE 8(1):e52733. https://doi.org/ 10.1371/journal.pone.0052733

Walther GR, Post E, Convey P, Menzel A, Parmesan C, Beebee TJC, Fromentin JM, Hoegh-Guldberg O, Bairlein F (2002) Ecological responses to recent climate change. Nature 416:389-395

Wilcox DA (1989) Migration and control of purple loosestrife (Lythrum salicaria L.) along highway corridors. Environ Manag 13(3):365-370. https://doi.org/10.1007/ bf01874916

Wróbel M, Tomaszewicz T, Chudecka J (2006) Floristic diversity and spatial distribution of roadside halophytes along forest and field roads in Szczecin lowland (West Poland). Pol J Ecol 54(2):303-309

Zając A, Zając M (2001) Distribution Atlas of Vascular Plants in Poland. Laboratory of Computer Corology. Institute of Botany, Jagiellonian University, Cracow

Zeeman BJ, Minden V, Morgan JW (2018) Non-native plant cover and functional trait composition of urban temperate grasslands in relation to local-and landscape-scale road density. Biol Invasions 20(10):3025-3036. https://doi.org/ 10.1007/s10530-018-1756-6

Zwaenepoel A, Roovers P, Hermy M (2006) Motor vehicles as vectors of plant species from road verges in a suburban environment. Basic Appl Ecol 7:83-93. https://doi.org/10. 1016/j.baae.2005.04.003

\section{Literature review}

Angersbach R (2012) Fundmeldungen-Neufunde-Bestätigungen-Verluste. Bot Nat Hessen 24:107-134

Baker LM (2005) Contributions to a catalogue of alien plants in Tasmania I. Pap proc R Soc Tasmania 139:33-48

Breitfeld M, Horbach HD (2006) Plantago coronopus L. jetzt auch in Oberfranken. Ber Bayer Bot Ges 76:129-134

Ciardo F, Hoffer-Massard F (2006) Deux Espéces halophiles nouvelles pour la suisse: Spergularia salina J. et C.Presl et Catapodium loliaceum (Hudson) Link. Bull Cercle Vaudois Bot 35:73-76

Diaz Gonzalez TE, Penas Merino A, Herrero Cembranos L, Perez Morales C, Llamas Garcia F, Terron Alfonso A (1988) Estudio de Los Herbazales nitrofilos vivaces y comunidades ruderal viarias de la provincia de leon (NW de EspastA). Acta Bot Barcelona 37:113-131

Feltwell J, Philp E (1980) Natural History of the M20 Motorway. Trans Kent Field Club 8:101-114

Buhr C, Herrmann A, Nogatz T, Kummer V (2017) Beitrag zur Flora des Potsdamer Stadtgebietes V. Bot Ver Berlin Brandenburg 149:73-134

Dickoré WB, Springer S (2016) Weitere Notizen zur Flora von München. Ber Bayer Bot Ges 86:262-276

Diewald (ex verb.). In: Gerstberger P (2001) Plantago coronopus subsp. commutata als Straßenrandhalophyt eingebürgert in Mitteleuropa. Tuexenia 21: 249-256

Ehmke W (2015) Fundmeldungen-Neufunde-BestätigungenVerluste. Bot Nat Hessen 28:102

Eichler M (2014) Fundmeldungen-Neufunde-BestätigungenVerluste. Bot Nat Hessen 27:91

Feder J (2008a) Das Japanische Liebesgras Eragrostis multicaulis STEUD. in den Heidekreisen und im übrigen Nordwestdeutschland (mit Bremen). Floristich Not Lüneburg Heide 16:13-24

Feder J (2008b) Die Besonderheiten der rezenten Flora im Bereich der Regionalstelle Bremen. Brem Bot Brief $1: 23-24$

Feder J (2012) Bemerkenswerte Pflanzenfunde an Straßen und auf Plätzen in Niedersachsen und Bremen (2011). Brem Bot Brief 14:10-43

Gerstberger P (2001) Plantago coronopus subsp. commutata als Straßenrandhalophyt eingebürgert in Mitteleuropa. Tuexenia 21:249-256

Gregor T, Hodvina S, Barth U, Bönsel D, Feuring C, Uebeler M (2012) Weiterführung der hessischen Florenliste. Bot Nat Hessen 24:71-105

Gregor T (2014) Fundmeldungen-Neufunde-BestätigungenVerluste. Botanik Nat Hessen 27:97

Gregor T (2015) Fundmeldungen-Neufunde-BestätigungenVerluste. Botanik Nat Hessen 28:110

Gutte P, Fischer J (2017) Botanische Neufunde aus den Jahren 2015 und 2016. Sächs Florist Mitt 19:55-62

Hohla M (2012) Bromus sitchensis-neu für Österreich, Plantago coronopus neu für Oberösterreich sowie weitere. Beiträge zur Kenntnis der Flora des Innviertels. Stapfia 97:180-192

Hohla M (2014) Hystrix patula - neu für Österreich, sowie weitere Beiträge zur Flora von Oberösterreich, Salzburg, Steiermark und Vorarlberg. Stapfia 101:83-100 
Hohla M (2018) Physalis grisea und Sedum pallidum neu für Österreich sowie weitere Beiträge zur Adventivflora von Österreich. Stapfia 109:25-40

Kaplan Z, Koutecký P, Danihelka J, Šumberová K, Duchacek M, Štepánková J, Brůna J (2018) Distributions of vascular plants in the Czech Republic. Part 6. Preslia 90(3):235-346

Kovács D, Lengyel A (2015) Adatok a Plantago coronopus L. hazai elterjedéséhez. Kitaibelia 20(2):306-306

Křenová Z, Chocholoušková Z, Zýval V (2012) Effects of applying deicing salt to roads in protected areas: a preliminary study in the Bavarian Forest National Park. Eur J Environ Sci 2(1):56-61. https://doi.org/10.14712/ 23361964.2015.39

Krippel Y, Helminger T, Colling G (2018) Notes floristiques. Observations faites au Luxembourg (2016-2017). Bull Soc Nat Luxemb 120:57-76

Kulbrock P, Lienenbecker H, Kulbrock G (2007) Beiträge zu einer Neuauflage der Flora von Bielefeld-Gütersloh Teil 8. Ber Naturwiss Ver Biel Umg 47:161-255

Kummer V, Petrick W, Illig H (2015) Nachtrag zur „Flora des Spreewaldes". Bot Ver Berlin Brandenburg 148:129-154

Otto HW, Gebauer P, Härtel H, Hardtke HJ (1997) Floristische Beobachtungen 1996 in Oberlausitz und Elbhügelland. Ber Naturforsch Ges Oberlausitz 6:57-82

Pagitz K, Pagitz-Lechner C (2015) Neues zur Neophytenflora Nord- und Osttirols (Österreich). Neilreichia 7:29-44

Roller O (2003) Fund des Krähenfuß-Wegerich (Plantago coronopus) am Straßenrand der Autobahn 65 bei Neustadt an der Weinstraße. - Pollichia-Kurier 19(4):14-15

SCHMIDT D (2019) Vonalas létesítmények mellett terjedő növények Vas megyében. - Vasi Szemle 73(2):160-174

Schmidt D, Dítětová Z, Horváth A, Szűcs P (2016) Coastal newcomer on motorways: the invasion of Plantago coronopus in Hungary. Studia Bot Hung 47(2):319-334. https://doi.org/10.17110/studbot.2016.47.2.319

Schmidt D, Bauer N, Fekete R, Haszonits G, Süveges K, Molnár VA (2020) A csókalábú útifü (Plantago coronopus) folytatódó térhódítása Magyarországon: continuing spread of Plantago coronopus along Hungarian roads. Kitaibelia 25(1):19-26. https://doi.org/10.17542/kit.25.19

Schönfelder I (2014) Beobachtungen zu Vorkommen einiger neophytischer Arten 2012/13. Inf Florist Kart Thür 33:39-42

Trigo MM, Fernandez-Ruiz MC, Salvo AE (1990) Sobre la palinología de las especies anemófilas más frecuentes en bordes de caminos de la ciudad de Málaga. In: FernándezFernández MC, Garrido MR, Rodríguez-García IM, Romero-García AT (eds) Blanca López G, Díaz de la Guardia C. Polen, Esporas y sus aplicaciones. Universidad de Granada, Berlin pp, pp 355-362

van Dijk H, Wolff K, De Vries A (1988) Genetic variability in Plantago species in relation to their ecology. Theor Appl Genet 75:518-528. https://doi.org/10.1007/bf00261254

Wünche AE, Gebauer P, Hardtke HJ, Otto HW (2016) Floristische Beobachtungen 2015 in Oberlausitz und Elbhügelland. Berichte der Naturforschenden Gesellschaft der Oberlausitz 24:51-68

Zange R (1994) Plantago coronopus Linnaeus in Hessen. Bot Nat Hessen 7:55-60

Publisher's Note Springer Nature remains neutral with regard to jurisdictional claims in published maps and institutional affiliations. 